\title{
6. Country
}

\section{Gabriel Egan}

T T IS OFTEN REMARKED THAT in British Renaissance drama landscapes are created in the minds of the audience rather than represented visually on the stage, and little or no scenery was used. An inventory of properties owned by the Admiral's Men in 1598 includes a city of Rome, a rainbow, a cloth of the sun and moon, two moss banks, a rock, a hell-mouth, a couple of tombs, a bed, a couple of trees, and a great variety of smaller objects, such as a wooden leg and various swords, shields, and crowns (Foakes and Rickert 319-20). It seems that there was some attempt, then, to dress the stage with realistic representations of the fictional environments in the drama, although the surviving scripts seldom call for large properties to be brought out. Instead, the plays clearly use language to construct their settings, as with Northumberland's "I am a stranger here in Gloucestershire. / These high wild hills and rough uneven ways / Draws out our miles and makes them wearisome" in Shakespeare's Richard II (R2 2.3.3-5). Recurrently in Shakespeare, responses to the landscape around them exist primarily to indicate characters' moods and motivations. Northumberland's description of the tedium of walking over uneven ground allows him to flatter Bullingbrook that his company and conversation make "the hard way sweet and delectable" ( $R 2$ 2.3.7).

In Shakespeare's plays, the experience of landscape is subjective, and on a stage that does not show the environment, characters may disagree about it. Shakespeare used such disagreements from almost his first play to almost his last. In Titus Andronicus, Tamora tries to seduce Aaron in the forest by extolling its beauty:

My lovely Aaron, wherefore look'st thou sad

When everything doth make a gleeful boast?

The birds chant melody on every bush,

The snakes lies rollèd in the cheerful sun,

The green leaves quiver with the cooling wind

And make a chequered shadow on the ground.

Under their sweet shade, Aaron, let us sit.

(Tit. 2.3.10-16)

Eighty lines later, to convince her sons that she was in danger from Bassianus and Lavinia, Tamora describes the same place in opposite terms:

These two have 'ticed me hither to this place.

A barren detested vale you see it is;

The trees, though summer, yet forlorn and lean,

Overcome with moss and baleful mistletoe.

Here never shines the sun, here nothing breeds

Unless the nightly owl or fatal raven.

(Tit. 2.3.92-97)
In The Tempest, Shakespeare closed the gaps between the conflicting descriptions, so that Gonzalo marvels to Adrian, "How lush and lusty the grass looks!," and is answered in the next line by Antonio's "The ground indeed is tawny" (Temp. 2.1.57-59). On a bare stage, there is nothing to tell us which of them is right.

According to Robert N. Watson, anxiety about the relationship between reality-in-itself and perception pervaded cultured minds in the late Renaissance, and a desire to go "back to nature" expressed a craving for unmediated knowledge, for an originary Edenic certainty. Watson traces what he calls epistemological crises in Shakespeare's plays, showing that the new sciences' categorizations of the world could look like the start of a frightening rupture from reality. As the telescope and the microscope revealed new worlds, some people realized that old assumptions about humankind's place in the universe might turn out to be fantasies based on ignorance of how things really are. Always lurking behind the subjectivist view is an unspoken fear that our systems of perceiving and classifying the world do not so much reflect reality as constitute it. The relationship between the "out there" and the representations of it changed radically in the sixteenth century as the new art of cartography was developed. The making of maps responded to, and further facilitated, Elizabethan England's ability to extend its power in overseas colonies - starting with Ireland but soon farther afield - and to develop at home new relationships between the land and the people on it.

\section{MAPS AND PANORAMAS}

For many practical purposes, such as travel, taxation, and governance, a representation that offers a bird's-eye view of the land is preferable to a landscape seen from ground level. A number of pictures from Shakespeare's time try to include both perspectives at once; for example, offering a bird's-eye view of a city in the top half of the picture but gradually shifting perspective in the lower half so that by the bottom the picture has become a panorama. The map of London by Georg Braun and Franz Hogenberg in their book Civitates Orbis Terrarum, published in Cologne in 1572 , is typical of this style. An alternative was the somewhat more realistic reverse arrangement with the bottom half being a bird's-eye view and the top spreading into a panorama, as indeed a bird would see looking directly down and then toward the horizon.

The countryside of Shakespeare's time was much less mapped than the cities, and there was no complete atlas for the whole country until John Speed's The Theatre of 
the Empire of Great Britaine was published in 1612. (The most familiar use of the word "theatre" was not as a playing place but as a book wherein was offered "a 'view' or 'conspectus' of some subject" [OED theatre, theatre $n$. ${ }^{\dagger} 7$ ].) Of course, manuscript maps of all kinds were in use long before then, although they were relatively expensive. Shakespeare brings maps onstage in just two scenes, both of them concerned with a three-way division of the country. In Henry IV, Part 1, Glendowr, Mortimer, and Hotspur agree that the Welshman shall possess all of Wales west of the river Severn, Mortimer shall have England from the Severn to the river Trent, and Hotspur all of the land north of the Trent. Hotspur complains that the winding course of the Trent, marking the edge of his territory, robs him of valuable land ( $1 H_{4}$ 3.1.93-102), and proposes to alter the river's course with "a little charge" (1H4 3.1.107-o8), meaning explosives. With the mapping of the countryside, Shakespeare seems to say, comes the impulse to control and reshape it: rather than altering the map, Hotspur imagines remaking the world it represents. The map seems to feed a fantasy of control that is particularly ironic since the rebels have yet to fight the battles that could win them these spoils to divide. The scene of the division of the kingdom in King Lear is similarly layered with ironies. Lear calls for the map that he says shows the three portions, and challenges each daughter to win her allocation, but when Regan outdoes her elder sister, she is rewarded with an equal, not an enhanced, share: "this ample third of our fair kingdom, / No less in space, validity, and pleasure / Than that confirmed on Gonoril" (Lear 1.1.75-77). When Shakespeare puts an actual map on the stage - and these are the only two occasions - dangerously deluded men carve up the countryside.

The word map is much used by Shakespeare, not about physical documents but rather about the way that experiences write themselves on a person. The lines on Malvolio's smiling face remind Mariah of "the new map with the augmentation of the Indies" ( $T N_{3}$.2.75), but more commonly the face takes an impression of something larger than itself, as a map does when being inscribed by its maker. Richard II's queen sees her husband, just as Henry VI sees Gloucester, as a "map of honour" ( $R_{2}$ 5.1.12; 2 H6 3.1.203), Titus sees his ruined daughter as a "map of woe" (Tit. 3.2.12), and Capulet his apparently dead daughter as a "map of misery" (Romeo and Juliet Q1 4.4.62). The face of sleeping Lucrece, before her rape, is a "map of death" (Luc. 402), and the face of the narrator's "friend" is a "map of days outworn" (Son. 68.1). As Peter Whitfield points out (see introduction to Part I, "Mapping Shakespeare's World"), the idea that the human body is a microcosm of the wider universe remained very much alive in Shakespeare's time. The macrocosm-microcosm relationship is a kind of mapping, as Menenius indicates when asking the new tribunes to read "the map of my microcosm," meaning his face (Cor. 2.1.61).
As well as one's experiences, one's travels could write themselves on the person. Henry IV notices that Sir Walter Blunt, bringer of news from the battle of Holmedon, is "Stained with the variation of each soil / Betwixt that Holmedon and this seat of ours" ${ }_{1} \mathrm{H}_{4}$ 1.1.64-65). Sometimes in Shakespeare the very fact that characters travel from place to place matters in the story; for example, the various journeys that bring everyone together at Dover for the climax of King Lear, including Edgar, who, as Tom O'Bedlam, claims to know the way intimately: "Both stile and gate, horseway and footpath" (Lear 4.1.55). These journeys are not depicted or described, and in Shakespeare characters often travel as if through hyperspace, being seen to set off and arrive but not visible en route. The exceptions to this rule cluster toward the end of Shakespeare's career, when he changed his writing style in a collection of plays, the romances Pericles, The Winter's Tale, Cymbeline, and The Tempest, in which travel - especially by sea - features largely. Just what stimulated this change of style is not clear, but some biographical facts can throw light on Shakespeare's own experience of the dislocations of travel.

\section{From Stratford-upon-Avon TO LONDON AND BEYOND}

Shakespeare was a country boy, and as Mark Eccles has pointed out, he "chose to be known as William Shakespeare of Stratford upon Avon" (Eccles v) despite making his career in London. Stratford-upon-Avon was a small market town with a population of about 2,000 that served as an exchange point for the produce of the surrounding fields and villages. The countryside around Stratford, beautiful as it was and is, was inescapably a place of production, of sweaty work, rather than recreation. We see this reflected in Shakespeare's rural characters' comments on their environments. Although he received a classical education at the local grammar school, in London Shakespeare must have sounded, and been perceived as, distinctly provincial.

From his reading, Shakespeare knew a lot about Greek and (especially) Roman history and culture, but for what was probably his first play, The Two Gentlemen of Verona, he decided on an Italian setting, as he would for nine more plays if we include Measure for Measure, which Thomas Middleton subsequently transposed to Vienna (Taylor). For many of Shakespeare's plays, the country in which the events are supposed to take place is immaterial. The settings are mostly European cities and the courts and great houses of senior aristocrats, and the countryside in between these centers of culture is something to be gotten through, or else (occasionally) sought as a refuge, but almost never to be enjoyed on its own account. The action of The Two Gentlemen of Verona begins in Verona but shifts to Milan when the titular young gentlemen move 
there. With no regard for geographical accuracy or the famous beauty of the region, Shakespeare has his characters make by ship the 100-mile westward journey across Lombardy between these landlocked cities. The countryside figures briefly in the play, but only as a place of exile to which Valentine and his fellow outlaws resort.

The same pattern is followed in Shakespeare's The Taming of the Shrew, set in the same part of northern Italy. Petruccio arrives in Padua from his home in Verona, forty miles to the west, and brings his new bride, Katherine, home, by land this time. The return journey to her father's house in Verona is dramatized (Shr. 4.6) only to show Katherine's exasperated acquiescence to Petruccio's mind games and not to convey anything of the Italian countryside. The countryside is not quite absent, however, since Petruccio prepares for this journey by having his horses gathered at the end of the very English sounding "Long Lane" (Shr. 4.3.183), of which Warwickshire had several, the nearest being in Keresley, two miles northwest of Coventry. The story of Italian wife taming is in fact an inset drama, for the play starts in England with a drunken tinker, Christopher Sly, being thrown out of a drinking house for not paying his bill and taken up by a lord, fresh from hunting, for whom some itinerant actors perform the Italian story.

This framing device contains the names of three places Shakespeare probably knew from the area where he grew up (Shr. Induction 2.17-20). Sly identifies himself as "Old Sly's son of Burton Heath," which probably refers to Barton-on-the-Heath, sixteen miles south of Stratford and home to Shakespeare's mother's sister, Joan Lambert (née Arden). For confirmation, Sly suggests asking "Marian Hacket, the fat ale-wife of Wincot." There is a hamlet called Wincot four miles south of Stratford, just half a mile south of a hamlet called Willicote, and either or both of these might be intended, since $n$ and $l$ sounds were interchangeable, as in Hamnet/Hamlet. Alternatively, Wilmcote, the home of Shakespeare's mother, three miles northwest of Stratford, might be meant. The Third Servingman reports that Sly, in his deranged (in reality, drunken) dreaming, raved about several people, including "old John Naps of Greet" (Shr. Induction 2.92), which probably refers to the hamlet of Greet about twenty miles southwest of Stratford. Shakespeare drew on the names of real English places he knew, but cannot have expected his audience to know them too since these hamlets were tiny. Revealing perhaps the writer's self-alienation, in order to frame a story about sexual and financial intrigues among the wealthy burghers of far-off Italy, the country boy turned London dramatist put obscure Warwickshire place-names into the mouth of a drunken tinker.

When he turned to writing English history plays, Shakespeare took more interest in the emotionally evocative value of the countryside. Shakespeare did not invent the history play but rather took it over from its first highly successful exponents, the Queen's Men of the 1580s, with whom he may have worked. From their plots and form, and a careful reading of the prose chronicles of Edward Hall and Raphael Holinshed, Shakespeare created a pair of plays, The Contention of York and Lancaster (later renamed Henry VI, Part 2) and Richard Duke of York (renamed Henry VI, Part 3), that created a wave of London interest, popular and intellectual, in the new talent from Warwickshire. The first of them began, as the Roman poet Horace advised, in medias res (in the middle of things), with Henry VI's marriage to the French princess Margaret of Anjou to consolidate a temporary peace in England's incessant wars against her people. As he would again later with the maps in Henry IV, Part 1, and King Lear, Shakespeare used a property document to dramatize the transfer of ownership of land, here certain regions of France won by Henry V and now to be returned. The Duke of Gloucester is so upset at this transfer that he breaks off his formal public reading of the articles of agreement, letting the paper fall from his hands at the news that the price England has to pay for its king marrying the French princess is that "the duchy of Anjou and the county of Maine shall be released and delivered to the King her fa-" (2H6 1.1.48-50). Salisbury calls these lands "the keys of Normandy," and his son Warwick thinks of them as lost "cities" ( 2 H6 1.1.112, $2 H 6$ 1.1.118) rather than lands. In the ensuing civil strife, the lands of England are fought over, but there is no sense that their value as lands is felt: possessions in France and Ireland are chips in the political games played in England, not real places full of country people.

When Gloucester is murdered in his bed, however, Shakespeare gives to "the proud Lord of Warwickshire" (2H6 3.2.201) - that is, the Earl of Warwick - a pair of speeches employing images from countrylife. Gloucester's death in bed cannot have been natural, Warwick decides, because "His well-proportioned beard [is] made rough and rugged, / Like to the summer's corn by tempest lodged" (2H6 3.2.175-76), and using the Midlands word for a kite, he asks, "Who finds the partridge in the puttock's nest / But may imagine how the bird was dead" (2H6 3.2.191-92). Perhaps again betraying an authorial anxiety about rural origins, the Warwickshire lord is accused of being the bastard son of a "stern untutored churl" (2H6 3.2.213) and not a nobleman at all. The depiction of the country men of Kent who support Jack Cade's rebellion, haters of the cultured and learned, might also be understood as the arriviste dramatist's abnegation of his rural origins. At the height of Cade's uprising, the country/city polarity is invoked only to be inverted: the Kentishman and his followers enter and temporarily hold the city of London itself, and the court retires for safety to the town of Kenilworth, about fifteen miles northeast of Stratford-upon-Avon. The inversion is soon righted and Cade is on the run, next seen in a setting to which Shakespeare repeatedly returned: a garden, standing as a tamed piece of countryside. This one is the garden of Sir Alexander Iden - or Eden in Holinshed's 
Chronicles - where Cade feels the curse of Adam, hoping to feed on the cultivated plants ( $2 \mathrm{H} 64.9$ ).

In these early plays, the countryside emerges only fitfully in similes and metaphors - recollections perhaps of Shakespeare's youth - rather than as a place he chooses to locate his dramas. With A Midsummer Night's Dream in 1595, however, Shakespeare set most of a play outdoors, with the court of Athens departed from in act 1 and returned to in act 5. Yet the characters he puts into this essentially English countryside are city dwellers artisanal "mechanicals" and aristocratic lovers - and supernatural spirits who range across the entire globe. Significantly, Shakespeare avoids showing native country folk, so no one is at home in this play's countryside. The German word unheimlich (unhomely) captures this sense of the countryside as an alien place of fear and psychological disturbance, in which easily is "a bush supposed a bear" (MND 5.1.22) and clothing is torn away by plants that seem alive and malicious: "For briers and thorns at their apparel snatch; / Some sleeves, some hats - from yielders all things catch" (MND 3.2.29-30). At least, that is the countryside at night.

Images of the countryside in daytime are evoked to stand for traditions and certainties overturned by the disruptions dramatized in the play, most obviously the conflict between Titania and Oberon. (See Figure 9.)

It is the unseen country laborers who suffer:

The ox hath therefore stretched his yoke in vain,

The ploughman lost his sweat, and the green corn

Hath rotted ere his youth attained a beard.

The fold stands empty in the drownèd field,

And crows are fatted with the murrain flock.

(MND 2.1.93-97)

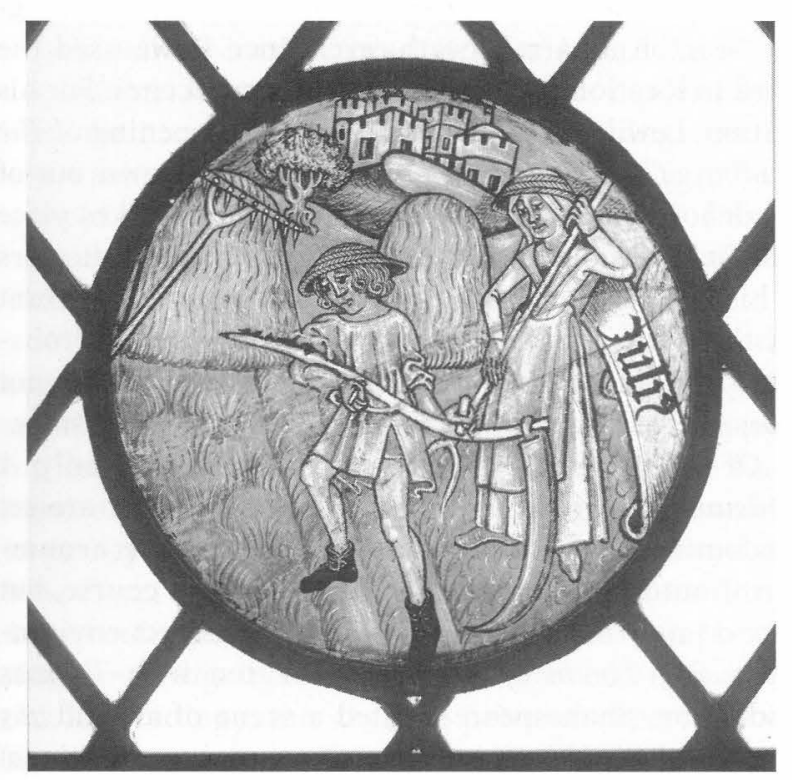

9. Labours of the Month (July) stained glass, c. 1450-75. (C) Victoria and Albert Museum, London.
Curiously, this apparently disastrous disruption of countryside labor is but an extreme case of what the spirits do all the time. The fairy who boasts of wandering "Over hill, over dale, / Thorough bush, thorough brier, / Over park, over pale" (MND 2.1.2-4) on Titania's errands identifies Robin Goodfellow as a spirit given to "Skim milk, and sometimes labour in the quern, / And bootless make the breathless housewife churn, / And sometime make the drink to bear no barm" (MND 2.1.36-68). That is, he interferes in the processes by which milk creams and turns to butter and ale is fermented, which were little understood in the period and hence failure was blamed on invisible malevolent agency. Seen in this light, the fairies are everyday aspects of the countryside rather than forces against it, which is why Titania's "pensioners" (the royal bodyguard) are cowslips whose ears must be adorned with dewdrops as pearls (MND 2.1.10-15). Likewise are Titania's servants Peaseblossom, Cobweb, Mote, and Mustardseed, whom we are meant to understand as tiny figures. Disturbingly to modern sensibilities, their duties toward Bottom visit violence on other small creatures:

Feed him with apricots and dewberries,

With purple grapes, green figs, and mulberries;

The honeybags steal from the humble-bees,

And for night tapers crop their waxen thighs

And light them at the fiery glow-worms' eyes

To have my love to bed, and to arise;

And pluck the wings from painted butterflies

To fan the moonbeams from his sleeping eyes.

(MND 3.1.158-65)

The images are at once charmingly rural and nauseatingly cruel, and we need not assume that our sensibilities are more attuned to this than those of the first audiences and readers. In Shakespeare's countryside, elite pleasures are closely affined with violence.

Rounding off her account of the recent climate change ("The seasons alter ..."), Titania mentions its effect on rural recreation: "The nine men's morris is filled up with mud, / And the quaint mazes in the wanton green / For lack of tread are undistinguishable" (MND 2.1.98-100). The former seems to be an oversized outdoor version of a traditional board game, and the unseasonable weather spoiling it is also disrupting gardening: "hoary-headed frosts / Fall in the fresh lap of the crimson rose". (MND 2.1.108). These are low-class rural pleasures, and they are described in passing, not dramatized. The aristocratic recreation of hunting with dogs, on the other hand, is directly portrayed at the start of the fifth act, and with apparent affection for the hounds whose ears "sweep away the morning dew" (MND 4.1.120) and whose collective barking is like music: "matched in mouth like bells, / Each under each. A cry more tuneable / Was never holla'd to nor cheered with horn" (MND 4.1.122-24). This image of 
musical harmony anticipates the harmonious reconciliation of the marriage conflicts with which the play began, but perhaps here, too, Shakespeare wanted us to fall for a charming bucolic image in order to be repelled at the violence it implies.

There are good reasons to suppose that Shakespeare wanted us to feel sympathy for hunted animals; for example, in the Princess of France asking "where is the bush / That we must stand and play the murderer in?" and lamenting that fashionable custom requires her "to spill / The poor deer's blood that my heart means no ill" (LLL 4.1.8-9, LLL 4.1.34-35). This differs from Theseus's hunting because by prearrangement the animals will be forced past the French ladies who will shoot them with arrows, and hence it takes place within a park, an artificially maintained version of the countryside stocked with animals for aristocratic recreation. According to a long-standing legend first widely circulated in Nicholas Rowe's biography of Shakespeare (which appeared as a preliminary to his 1709 edition of the works), the young Shakespeare's migration from Stratford-upon-Avon to London in the 1580 os was a flight from punishment for his part in robbing a park owned by Sir Thomas Lucy at nearby Charlecote. A group Shakespeare fell in with, says the legend, made a habit of stealing deer, but in fact Lucy's park had no deer, only rabbits. If true, the story is rather less faux aristocratic, and less impressive, than is commonly thought.

Shakespeare's second extended dramatization of life in the countryside came with As You Like It at the end of his decas mirabilis, the 1590s, and in performance the play's rabbits and deer have, with some justice, often been shown to the audience. The hunting in As You Like It is for subsistence, and although it moves Jaques to pity (AYLI 2.1.25-68), the justification of need is amply present; as Orlando puts it to Adam: "If this uncouth forest yield anything savage I will either be food for it or bring it for food to thee" (AYLI 2.6.6-7). Yet, as in Love's Labour's Lost, the metaphoric associations of falling in love and recreational hunting suffuse the play, aided by the homophones deer/dear and hart/heart, and the sense that a sojourn in the country acts as a restorative. In this reading, there is no real countryside in Shakespeare, only bucolic contrasts to urban life. If Shakespeare began his career by renouncing the Warwickshire in which he grew up, it was in his mind at the turn of the century as his career peaked. Behind his most obviously urban play, The Merry Wives of Windsor, are recollections of Charlecote. In 160o, Sir Thomas Lucy brought an action for rioting and park breaking - the crimes Falstaff stands accused of - against those he thought responsible for his cherished granddaughter Elizabeth Aston marrying beneath herself and against his wishes, which he considered an abduction (Sokol). This indeed is deer stealing, if we allow for one of Shakespeare's favorite puns, deer/dear. The association of lust and hunting drove Shakespeare's first successful book, the narrative poem Venus and Adonis, and recurs in the classical myths he would have read at school, including the story of the Greek goddess Artemis (Roman equivalent Diana) punishing the hunter Aectaeon for watching her bathe by turning him into a stag that his own hounds destroy. The association was active at the other end of the social scale, too, in the hunting of rabbits rather than deer. Rosalind describes where she lives as the "skirts of the forest, like fringe upon a petticoat" and says she is as native to it "As the coney that you see dwell where she is kindled" (AYLI 3.2.327-30). As Kevin Quarmby has pointed out, coney was pronounced to rhyme with money (not pony) and was slang for vagina, so that behind Rosaline's simple rustic answer is a filthy one about sexual excitement (her own?), the verb kindling being commonly used in this sense.

As You Like It is remembered among Shakespeare's most beautiful poetical evocations of the countryside. The glimpses of country life it offers, however, are hard, and its labor is economically alienated: "I am shepherd to another man, / And do not shear the fleeces that I graze," says Corin (AYLI 2.4.77-78). We are far from Edenic yearning here, since only human activity makes the countryside bearable. In its uncultivated state, Shakespeare's countryside is a terrifying place. When he uses the word heath, which simply means open uncultivated ground, it is to mark a place of desolation and despair. The witches plan to encounter Macbeth "Upon the heath" after the opening battle, a place he describes as "blasted" (Mac. 1.1.6, Mac. 1.3.75). Fearing death by drowning, Gonzalo imagines the worst kind of place he would rather be, picturing "an acre of barren ground: long heath, broom, furze, anything" (Temp. 1.1.62-63). Editors and critics also have tended to imagine Lear on a barren heath, ever since Rowe used the word in location indicators for the storm scenes. For his edition, Lewis Theobald decided that the opening of The Taming of the Shrew, with drunken Sly thrown out of an alehouse to sleep it off in the open, also takes place on a heath, and added the necessary location indicators in his 1733 edition. Although there is no textual warrant for them, these additions speak of an intuition, probably correct, that for Shakespeare the countryside is not a hospitable place until it comes under human mastery.

Of the forty or so plays by Shakespeare, only $A$ Midsummer Night's Dream and As You Like It are set predominantly in the countryside. There are a number of outdoor scenes in his other plays, of course, but they do not treat the countryside as a distinct environment. For Timon of Athens, co-written with Thomas Middleton, Shakespeare created a scene of around 765 lines (broken up into multiple scenes in some editions) set entirely "in the woods" to which Timon has exiled 
himself. It is a scene of physical and emotional desolation, with nothing edible growing above ground, so that to survive Timon must dig for roots. The woods turn out to be not the ascetic's refuge that Timon is looking for: he is plagued with company and discovers gold, which reconnects him with the Athenians. A considerable part of Cymbeline takes place in the Welsh mountains and valleys, and again the emphasis is on the harshness of the environment, its inhospitability ameliorated only by cultural accomplishments such as Imogen-as-Fidele's "neat cookery" and Belarius's "ingenious instrument" (Cym. 4.2.52, Cym. 4.2.187). The recurrent contrast in Shakespeare is between the harsh countryside and the comforts of urban life. As Margot Heinemann has pointed out, the bareness of the early modern stage should not blind us to this contrast, nor should it encourage directors to show "the kind of Boar's Head tavern we often get at [the Royal Shakespeare Company productions in] Stratford, without so much as a chair or a table in sight to allow the actors to suggest the easy attraction of pub life" (Heinemann 224). Shakespeare encourages us, in other words, to reflect on the many pleasures of the indoor life.

\section{BACK TO STRATFORD-UPON-AVON?}

We know that Shakespeare came from Stratford-uponAvon and worked in London, and the common assumption is that in retirement he returned to small-town life in the heart of the Warwickshire countryside. Not long after his death in Stratford, Shakespeare was being referred to as a poet of nature. An inscription on his grave says that with his loss "Quick nature died," and in the preliminaries to the 1623 First Folio collection, his fellow actors John Heminges and Henry Condell described him as "a happy imitator of nature" and Ben Jonson called him the "Sweet swan of Avon." We should not assume, however, that nature has its modern sense here, for it could simply mean the way things are. Yet when John Milton, in his early poem "L'Allegro," celebrated the simple pleasures of the country life, he imagined he saw "sweetest Shakespeare, fancy's child, I Warble his native wood-notes wild."

Perhaps, though, Shakespeare was "of Avon" rather more literally than we have supposed. Clearly he spent a considerable amount of time in London, where his playing company mainly lived and worked, and we know some of the places he lodged. But in 1597 he invested in perhaps the grandest house in Stratford-upon-Avon, New Place, and it would have provided better conditions for extended periods of intense reading and composition than would digs in London. As Stanley Wells has pointed out, his reading rather than his personal experience was the primary resource for writing the plays, and most of the books he needed were heavy folios: Thomas North's translation of Plutarch, Ovid's Metamorphoses, Michel de Montaigne's Essays, Raphael Holinshed's Chronicles. Most likely, Shakespeare kept them in his study in Stratford-upon-Avon and got back there as often as he could (Wells 36-37). Using contemporary accounts of traveling the route, Wells reckoned that the Stratford to London journey could be made in two or three days, depending on the weather. If Shakespeare was a regular commuter, this would provide his most common communion with the countryside: not to be enjoyed at leisure - other than in recollections of his youth - but dashed through on a horse or in a carriage. Or perhaps only dashed in one direction and plodded wearily in the other: "How heavy do I journey on the way.... 'Thus far the miles are measured from thy friend" "(Son. 50.1-4). If this reflects actual journeys made by the poet, we cannot tell which of the two poles of his life, Stratford and London, he most minded leaving.

\section{SOURCES CITED}

Braun, Georg, and Franz Hogenberg. Civitates Orbis Terrarum. Cologne: 1572.

Eccles, Mark. Shakespeare in Warwickshire. Madison: U of Wisconsin P, 1961.

Foakes, R. A., and R. T. Rickert, eds. Henslowe's Diary, Edited with Supplementary Material, Introduction and Notes. Cambridge: Cambridge University Press, 1961.

Heinemann, Margot. "How Brecht Read Shakespeare." Political Shakespeare: New Essays in Cultural Materialism. Ed. Jonathan Dollimore and Alan Sinfield. Manchester: Manchester UP, 1985. 202-30.

Quarmby, Kevin. “'As the Cony That You See': Rosalind's Risqué Rabbits in As You Like It." Shakespeare 6 (2010): 153-64.

Sokol, B. J. "A Warwickshire Scandal: Sir Thomas Lucy and the Date of The Merry Wives of Windsor." Shakespeare 5 (2009): 355-71.

Taylor, Gary. "Shakespeare's Mediterranean Measure for Measure." Shakespeare and the Mediterranean: The Selected Proceedings of the International Shakespeare Association World Congress at Valencia 2001. Ed. Tom Clayton, Susan Brock, and Vicente Fores. Newark: U of Delaware P, 2004. 243-69.

Watson, Robert N. Back to Nature: The Green and the Real in the Late Renaissance. Philadelphia: U of Pennsylvania P, 2006.

Wells, Stanley. Shakespeare: For All Time. London: Macmillan, 2002.

\section{FURTHER READING}

Berry, Edward. Shakespeare and the Hunt: A Cultural and Social Study. Cambridge: Cambridge University Press, 2001.

Fitter, Chris. Poetry, Space, Landscape: Towards a New Theory. Cambridge: Cambridge University Press, 1995.

Klein, Bernhard. Maps and the Writing of Space in Early Modern England and Ireland. Basingstoke: Palgrave, 2001.

Nicolson, Marjorie Hope. Mountain Gloom and Mountain Glory: The Development of the Aesthetics of the Infinite. Ithaca: Cornell UP, 1959.

Sullivan, Garrett A. The Drama of Landscape: Land, Property, and Social Relations on the Early Modern Stage. Stanford: Stanford UP, 1998 . 